\title{
Science defeats all odds in US budget
}

\section{- Increases set for science agencies - NSF budget doubling back on target}

\section{Washington}

WhILE the US Congress continued its eleventh-hour assault on the federal budget deficit last week, science agencies were already breaking out the champagne. Despite grim predictions of acrossthe-board cuts, research funding is likely to outscore every other federal spending category with average increases of nearly 12 per cent likely in the final 1991 budget.

Two of the four top science agencies did even better with increases of about 13 per cent set as the House of Representatives and the Senate agreed on a compromise between their budget figures. The good news for the National Institutes of Health (NIH), the National Aeronautics and Space Administration (NASA) and the National Science Foundation (NSF) was a payoff that agency officials attribute to a year's concerted lobbying by scientists and their research advocates.

The NIH reaped much of the benefit with an increase that is almost 10 per cent over last year, and about 5 per cent over President Bush's request in January. Total NIH funding, including training and AIDS research, will be $\$ 8,307$ million in 1991. Controversial language calling for a four-year NIH spending plan which, among other things, would favour universities with low overhead costs (see Nature 347, 413; 4 October 1990) was retained in the conference report, and will effectively become law. Ten committees assembled by NIH will be deciding this week how to implement the language, so that NIH can report back to Congress within 30 days.

Buildings and facilities at NIH will get over $\$ 1,000$ million in new funds. That increase, 177 per cent over last year's appropriations, will largely go towards a child health/neurosciences building and a large office building on the NIH campus.

Other NIH highlights include the human genome project, which ended with just under $\$ 88$ million, somewhat better than the $\$ 66$ million the House had threatened earlier this year, but still far below the requested $\$ 108$ million and a disappointing ( 47 per cent) increase for a new project that was meant to double in size. Elsewhere in the US health budget, the Centres for Disease Control received an increase of nearly 18 per cent to $\$ 1,318$ million and the Alcohol, Drug Abuse and Mental Health Adminstration won a 10 per cent increase to $\$ 2,895$ million.

Overall, research advocates could find little not to like in the congressional numbers. "Biomedical research is extremely popular in Washington. Scientists worked hard to get that across and the message came through," says Gar Kaganowich, head of public affairs for the Federation of American Societies for Experimental Biology.

NASA, the largest US science agency, also did well, although it was only about half the ambitious 24 per cent rise President Bush had asked for in January. Total NASA funding is $\$ 13,868$ million, $\$ 1,646$ million over last year.

The Space Station and the Moon-Mars mission were the only major projects to be hit. In addition to cutting the president's budget request for the Space Station by $\$ 551$ million to $\$ 1,900$ million, the HouseSenate conference put a 10 per cent (including inflation) cap on any future rise in the starcrossed project's total cost. The conference report also requires that NASA re-examine the entire project. That process, which will take the form of a 90-day study, will begin immediately, according to a NASA spokesman. The impact of the 22 per cent cut in next year's funding will not be determined until the study is completed, NASA says.

As expected, Congress entirely deleted the Moon-Mars mission from the budget, for a saving of some $\$ 300$ million. On the plus side, the House-Senate conference restored all but $\$ 3$ million to the $\$ 148$

\begin{tabular}{lcc}
\hline \multicolumn{3}{c}{ US SCIENCE BUDGET (\$ million) } \\
\hline & 1990 & $1991^{*}$ \\
NIH & 7,450 & 8,307 \\
NASA & 12,221 & 13,868 \\
DOE† & 3,379 & 3,676 \\
NSF & 2,080 & 2,356 \\
\hline
\end{tabular}

* Budgets approved by House and Senate conference

† General Science and Energy Supply R\&D

million CRAF/Cassini paired cometary exploration probes. The Senate had previously recommended a $\$ 50$ million cut in the programme, which would have effectively cancelled CRAF (see Nature 347, 215; 20 September 1990). But heavy lastminute lobbying by planetary scientists apparently found a receptive audience.

Congress found far less to quibble with in NSF's budget. It granted the agency nearly all of its 1991 request, and for the first time in three years put the agency nearly on schedule for the long-promised doubling of its budget within five years. The only major cut was of almost all funds for the Laser Interferometer Gravitational Wave Observatory (LIGO), a project that NSF had hoped to start this year. Although $\$ 75$ million was deleted at the last minute from NSF's research request (Congress discovered that it could not make the military pay for the operation of NSF's Antarctic scientific stations), eliminating LIGO leaves only $\$ 28$ million in cuts to be spread out among all NSF's other science programmes. "I don't think it will mean any restructuring of priorities", says NSF budget officer Joel Whitter.

DOE science programmes fared less well in last week's congressional conferences. Although overall figures are up by about $\$ 300$ million - some nine per cent - the inflation rate is expected to rise by nearly that much as a result of a general slow-down in the US economy and the Middle East crisis. Within the DOE programmes, Congress cut $\$ 50$ million each from the budgets for magnetic fusion (which puts it 15 per cent below 1990) and general research. A DOE spokesman says that the agency has not yet decided whether to make a percentage cut across the board in those programmes or to target specific projects for reductions.

The Superconducting Super Collider (SSC) lost $\$ 75$ million from its $\$ 318$ million request but the conference report allows it to use $\$ 25$ million in 1990 construction funds that had been frozen in congressional action last year. Late last week, the Texas National Research Laboratory Corporation, which manages the $\$ 1,000$ million that the state of Texas has promised the project, voted to release $\$ 60$ million of its funds to more than make up for the remaining shortfall. The end result, says SSC director Roy Schwitters, is that the congressional cut will have "zero impact" on the project.

Elsewhere, Congress cut the Strategic Defense Initiative ('Star Wars') budget by $\$ 1,800$ million to $\$ 2,900$ million, the lowest level in five years, and a sign that the controversial programme may be near the end of its days. And in the transportation budget, Congress approved $\$ 10$ million in funding for research into US designs for magnetically levitated (maglev) trains, a technology that, based on superconducting magnets, has been under development in Japan for almost a decade.

Although Congress is expected to remain embroiled in budget negotiations throughout the week, the figures from last week's conferences are unlikely to change greatly before final congressional and presidential approval. "Right now it's a self-contained fight within the revenue [taxes] side," says NSF's Whitter. "Assuming those talks don't break down completely and make them turn to spending, these numbers should be pretty solid." President Bush has given Congress until today to complete the budget, although an extension (which would be the third this year) remains possible.

Christopher Anderson 